\title{
UDC 661.725.3
}

\section{CATALYTIC TRANSFORMATIONS OF ISOPROPANOL ON ALUMINUM $\eta-O X I D E$ MODIFIED BY HETEROPOLIC ACID}

\author{
E.A.Guseinova, S.E.Yusubova*, K.Y.Adzhamov \\ Azerbaijan State Oil and Industry University \\ *Research institute "Geotechnological problems of oil, gas and \\ chemistry", Azerbaijan State Oil and Industry University \\ elvira_huseynova@mail.ru \\ Received 04.03.2019
}

\begin{abstract}
Catalytic properties the aluminum $\eta$-oxide modified by phosphomolybdic heteropolyacid in the course of isopropanol transformation were studied. It is established that modifying leads to increase in its activity and selectivity on oxygen-containing products. With application of the scanning electronic microscopy, an elemental analysis and an IR-spectroscopy textural and spectroscopical features of the aluminum modified $\eta$-oxide are revealed and the mechanism of their influence on the catalytic activity in the process of isopropyl alcohol conversion was suggested.
\end{abstract}

Keywords: isopropyl alcohol, aluminum $\eta$-oxide, phosphomolybdic heteropolyacid, catalytic properties.

\section{https://doi.org/10.32737/0005-2531-2019-3-32-40}

Heteropolyacids (HPA) are among the most powerful proton acids, which are superior in strength to all known inorganic acids. HPA possessing valuable properties are used both as heterogeneous catalysts in redox and acid-type reactions, and as bifunctional catalysts [1-5]. As is known, the reaction rates in heterogeneous catalysis, occurring at the interface, are directly dependent on the specific surface of the solid phase, and given that HPA have a small specific surface area $(1-5) \mathrm{m}^{2} / \mathrm{g}$, this often limits their use as heterogeneous catalysts. There are works in which, in order to increase the specific surface area of the HPA, they were applied to solid inert carriers [6-8].

In connection with the promise of using HPA in heterogeneous catalysis, the question naturally arises about the possibility of immobilizing them on the surface of practically used carriers, for example, aluminum oxide. A huge number of original papers and reviews [9-17] are devoted to various aspects of the industrial use of aluminum oxide. Possessing thermal stability, ease of regeneration, high adsorption activity, aluminum oxide has found the widest use as an adsorbent, carrier, and also as a component of the most common catalysts and is used in various oil refining and petrochemical processes: reforming, hydrotreating, hydrocracking, etc. The mostly used modifications are $\gamma-, \eta-, \theta$ - and $\chi$-aluminum oxides, since they all have a developed surface, but differ in catalytic properties.
Despite numerous studies of aluminum oxide, in many cases this issue remains the focus of attention of scientists.

In this regard, of undoubted interest is the study of the specific features of influencing of the modification of aluminium $\eta$-oxide by a heteropolyacid on the catalytic properties exhibited by it in the process of isopropyl alcohol conversion. The choice of the $\mathrm{n}^{-}-\mathrm{Al}_{2} \mathrm{O}_{3}$ modification as the object of study is due to the fact that, according to the literature data [18], it has the highest specific surface area, which is maximal among aluminum oxides: $\eta-\mathrm{Al}_{2} \mathrm{O}_{3}>\gamma$ $\mathrm{Al}_{2} \mathrm{O}_{3}>(\chi+\gamma)-\mathrm{Al}_{2} \mathrm{O}_{3}>\delta-\mathrm{Al}_{2} \mathrm{O}_{3}>\theta-\mathrm{Al}_{2} \mathrm{O}_{3}>\kappa-\mathrm{Al}_{2} \mathrm{O}_{3}$ $>\alpha-\mathrm{Al}_{2} \mathrm{O}_{3}$, which is one of the important factors when modifying HPA.

\section{Experimental technique}

A catalyst of a given composition was prepared by impregnating aluminum oxide with a solution of HPA in an aqueous solution of ammonia (from the calculation of HPA with $\eta-\mathrm{Al}_{2} \mathrm{O}_{3}$ ) on a carrier calcinated in advance for 3 hours to $200^{\circ} \mathrm{C}$. During the process there were used:

1) bayerite (was calcinated during 3 hours at $300^{\circ} \mathrm{C}$ to obtain $\eta-\mathrm{Al}_{2} \mathrm{O}_{3}$ );

2) aqueous ammonia solution (GOST 376079 , mass fraction of ammonia, $\%$, not less than $10 \%$, concentration of $\left.90-100 \mathrm{~g} \mathrm{NH}_{3} / \mathrm{l}\right)$;

3) phosfomolybdic $\mathrm{HPA} \mathrm{H}_{7}\left[\mathrm{P}\left(\mathrm{Mo}_{2} \mathrm{O}_{7}\right)_{6}\right] \cdot \mathrm{H}_{2} \mathrm{O}$;

4) isopropyl alcohol (GOST 9805-84). 
The catalytic properties of the initial and modified $\eta-\mathrm{Al}_{2} \mathrm{O}_{3}$ were studied on a flowthrough installation in the temperature range $150-250^{0}$ with a flow rate of the feed of $75 \mathrm{~h}^{-1}$.

The analysis of the raw materials and liquid reaction products was carried out by chromatographic method on the device "CHROM 5" with a flame-ionization detector using a column filled with a sorbent CELIT C-22, with $17 \%$ polyethyleneglycol applied on a sorbent. The reaction gas products were analyzed on the chromatograph "CHROM 5" with a thermal conductivity detector. Diethyleneglycol ether and $n$-butyric acid ester deposited on INZ-600 Inzensky brick were used as a sorbent. The quantitative interpretation of the chromatographic peaks that make up the obtained catalyzate was determined by the method of absolute calibration and internal normalization.

The infrared spectra of motor oil were recorded on a Nicolet IS 10 spectrometer (Thermo Scientific) in the range of wave numbers from 400 to $4000 \mathrm{~cm}^{-1}$ and an expansion of $4.0 \mathrm{~cm}^{-1}$. The registered samples in the form of a drop were compressed between two transparent silicon windows to form a thin film (capillary layer).
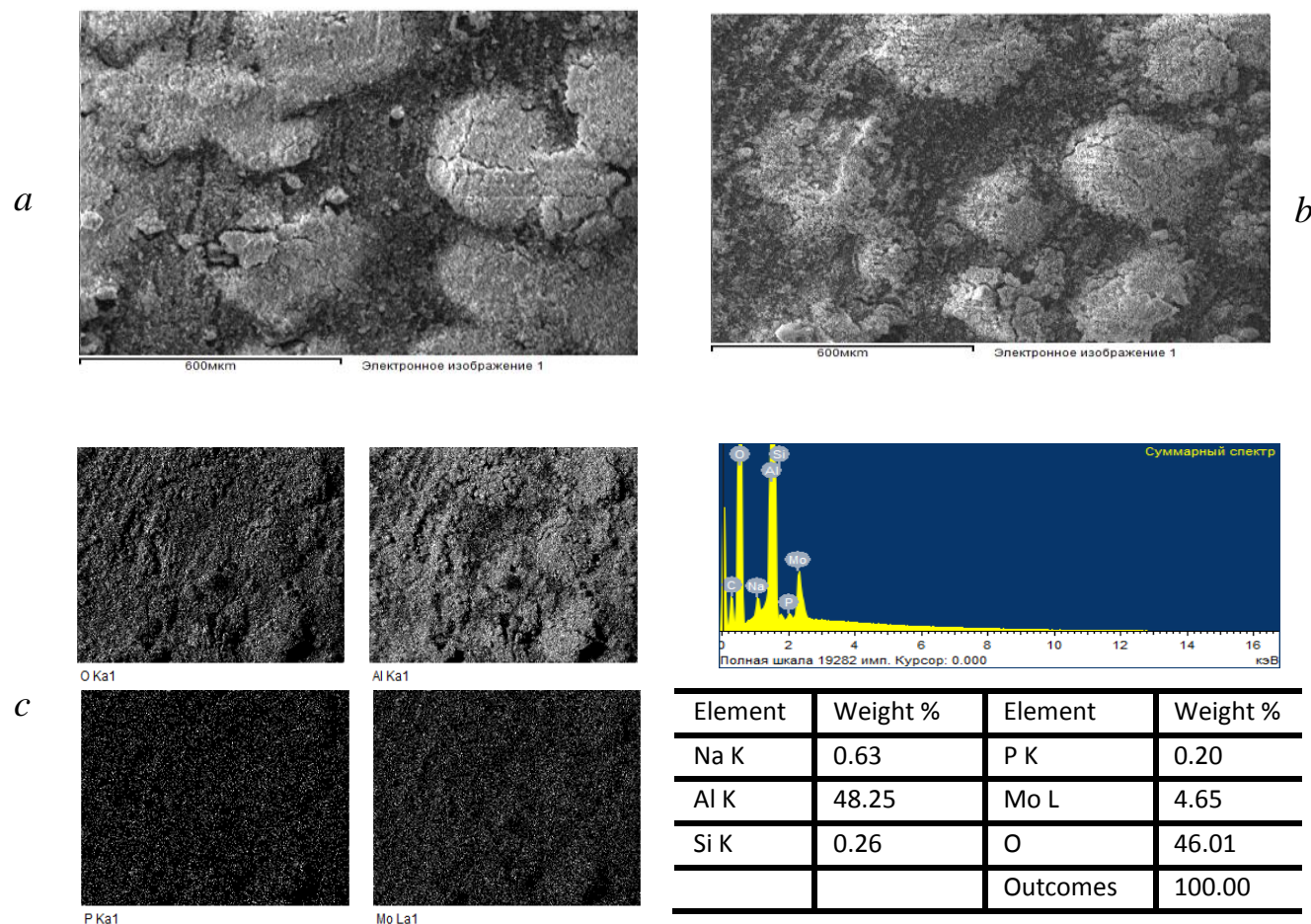

Fig.1. Microphotographies of the initial $\eta-\mathrm{Al}_{2} \mathrm{O}_{3}(a)$ and modified $(b) \mathrm{HPA} / \eta-\mathrm{Al}_{2} \mathrm{O}_{3}$, as well as X-ray maps of the distribution of chemical elements EDX-analysis of the HPA $/ \eta-\mathrm{Al}_{2} \mathrm{O}_{3}(c)$. carbon substrates mounted on copper grids.

\section{Results and discussion} in the heterogeneous catalysis.

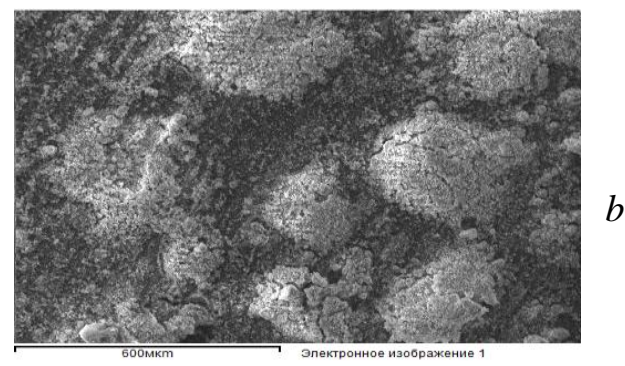

The surface morphology, as well as the elemental composition of the samples, were studied by scanning electron microscopy (SEM) methods on a JEOL JSM-6610 LV microscope with a $0.14 \mathrm{~nm}$ grating resolution (with integrated EDX analyzer (EDS, Genesis 4000, using a $\mathrm{Si}(\mathrm{Li})$ detector) at an accelerating voltage of $100 \mathrm{kV}$. The sample for SEM was fixed on

Surface morphology. Figure 1 shows electron microscopic images of the original and modified aluminium. As you can see, if the surface of an unmodified sample looks like closepacked large agglomerates (Figure.1, $a$ ), then after entering the HPA these formations have collapsed and are now represented by 2 types: highly dispersed particles of near-spherical shape (these data are in good agreement with the results of $\mathrm{X}$ ray phase analysis ) their units, whose size is $6 \mu \mathrm{m}$ and $400 \mu \mathrm{m}$, respectively (Figure. 1, $b$ ), and their loose packaging should provide a higher surface area, which, as mentioned above, is one of the necessary conditions the efficient use of the HPA

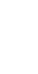


The X-ray mapping (Figure 1,c) and the semi-quantitative EDX analysis performed in addition to the SEM showed that when modifying the aluminum oxide HPA, molybdenum and phosphorus are equally distributed in the sample volume.

IR spectroscopic studies were carried out ex situ (Figure 2) for 2 types of aluminum oxide: unmodified and modified by HPA $\eta$ $\mathrm{Al}_{2} \mathrm{O}_{3}$ samples. All, the investigated samples of aluminum oxide, without exception, have two common signs:

1) the presence of a low-intensity vibrational mode - a transverse optical phonon, with a maximum located near $450 \mathrm{~cm}^{-1}$, which, according to the literature [11,19-22], indicates the formation of vibrations of the $\mathrm{O}-\mathrm{Al}-\mathrm{O}$ bond stretching, characteristic of crystalline aluminum oxide;

2 ) in the IR spectra, there is a single intense peak at $1632 \mathrm{~cm}^{-1}$, related to the deformation vibrations of the $\mathrm{O}-\mathrm{H}$ bonds of molecular water $\delta\left(\mathrm{H}_{2} \mathrm{O}\right)$, its splitting is observed; while the intensity of the latter in the modified samples is higher.

The subsequent comparative analysis showed that the following differences are inherent in the studied four samples.
1. In the original aluminum oxide (Figure 2 , a), before participation in the process, the surface $\mathrm{OH}$ groups are represented mainly by bridging $\mathrm{OH}-$ located between two aluminum atoms with coordination numbers 1 and 2 , as indicated by the bands at $3742 \mathrm{~cm}^{-1}$ (associated with two octahedral aluminum ions; the size of a proton affinity of PA $=1410-1440 \mathrm{~kJ} / \mathrm{mol}$ is specified in the work [23] that indicates average acidity inherent in it) and $3813 \mathrm{~cm}^{-1}$ (highfrequency $\mathrm{OH}$-group, it is bonded with a tetrahedral aluminum ion, according to data of the same authors of PA $=1440-1590 \mathrm{~kJ} / \mathrm{mol}$, therefore, these hydroxyl groups have minimum acidity) respectively; these strips of the same sample completely disappear after participation in the process what is probably bound to the happened superficial changes - education and selection of molecules of water and formation of Lewis acid $\left(\mathrm{Al}^{3+}\right)$ and base $\left(\mathrm{O}^{2}\right)$ centers (results of catalytic transformations of isopropanol in the presence of unmodified aluminum oxide accord with this model - existence mainly of Lewis's centers; in the modified samples, these bands are absent; these data indirectly allowed us to note the presence of aluminum vacancies in $\eta-\mathrm{Al}_{2} \mathrm{O}_{3}$ randomly distributed between tetrahedral and octahedral positions.

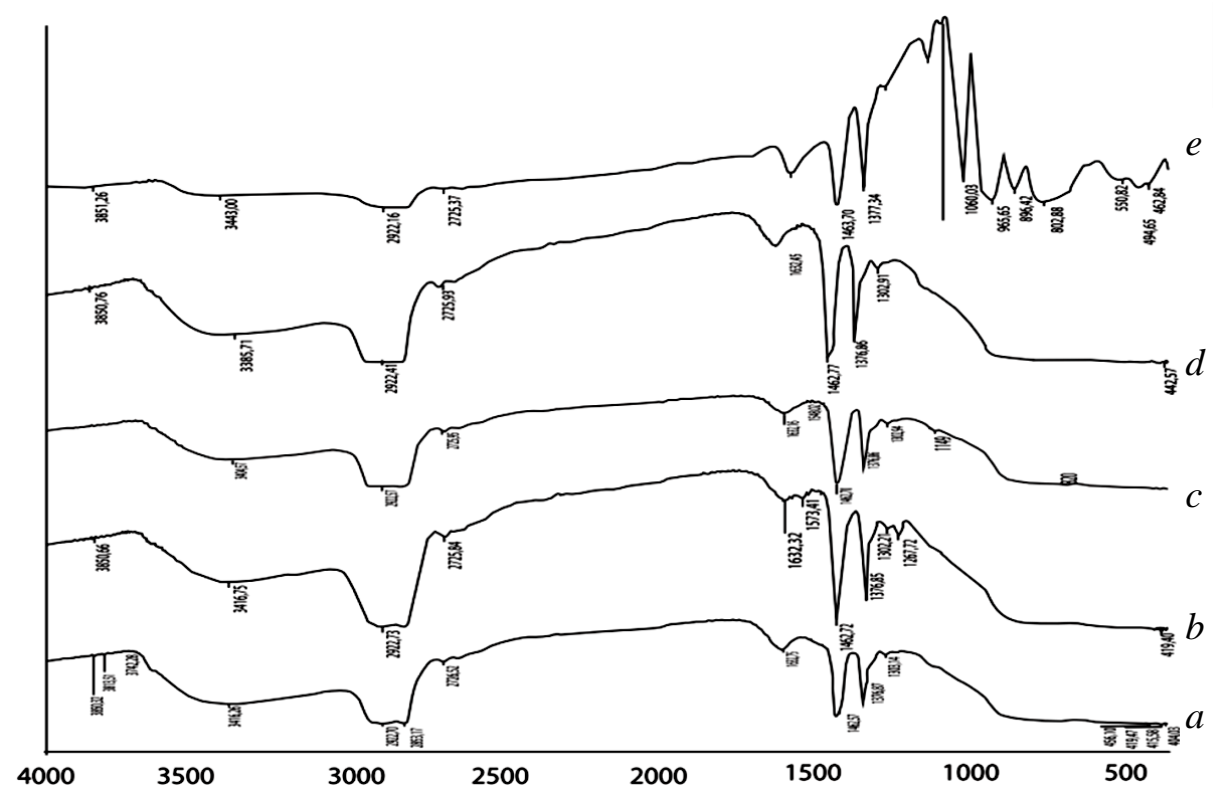

Fig.2. IR spectra of $\eta-\mathrm{Al}_{2} \mathrm{O}_{3}$ : original before catalysis $(a)$ and after $(b)$, modified before catalysis $(c)$ and after $(d)$, and also phosphomolybdic heteropolyacid $(e)$. 
2. In the spectrum of the unmodified sample, after participation in the catalytic process (Figure 2,b), the appearance of a transmission band at $1533.41 \mathrm{~cm}^{-1}$ is observed what indicates the presence of surface carbonate groups coordinated to $\mathrm{Al}^{3+}$; it is likely that these groups, strongly adsorbed during the process, block the active centers and are responsible for the rapid decline in the catalytic activity of this sample.

3. For all 4 samples of aluminum oxide in the region of $3100-3700 \mathrm{~cm}^{-1}$, corresponding to the absorption of valence vibrations of $\mathrm{O}-\mathrm{H}$ bonds, a wide intense absorption band is observed with a maximum at $3416 \mathrm{~cm}^{-1}$ (for unmodified), and shifted to a lower frequency region to 3404 and $3385 \mathrm{~cm}^{-1}$ (for modified samples; Figure 2, $c$ and $d$ ) what is probably due to the presence of the modifier; also noteworthy is the decrease in the intensity of the modified samples, which indicates the interaction of the modifier with the carrier;

4. The bands used for modifying the original HPA (Figure 2,e) at 462.84, 494.65, 550.82, 802.88, 896.42, 965.65, 1060.03, $1124.55,1167.45$, disappeared after being rubbed on aluminum oxide, what indicates the absence of a Keggin structure on the surface.

Catalytic properties. The choice of isopropyl alcohol as a model raw material is associated with a high level of scientific knowledge of the chemistry of this reaction, a large amount of accumulated practical material on the mechanisms of transformation of lower aliphatic alcohols and the ability to test the effect of the chemical composition of the modifier on the reaction direction [19-22].

Figure 3 shows the results of the change in the degree of conversion of isopropyl alcohol in the presence of $\eta-\mathrm{Al}_{2} \mathrm{O}_{3}$ at different temperatures and the process duration. As can be seen, a noticeable activity of $\eta-\mathrm{Al}_{2} \mathrm{O}_{3}$ began to appear already at $150^{\circ} \mathrm{C}$ : the maximum degree of alcohol conversion was $36.2 \%$. The temperature rise up to $200^{\circ} \mathrm{C}$ is accompanied by an increase in the degree of alcohol conversion by $7 \%$ and reached $43.1 \%$. At a temperature of $250^{\circ} \mathrm{C}$, the maximum rate of conversion of raw materials was noted $-51.8 \%$.

As can be seen from the data presented in the Figure 3, for all three temperatures studied, the feature of the influence of the process duration and breaks "for rest" on the process indicators was noted: each time after the process started, the catalyst development took 2 hours; after reincorporation, the primary indicators were lower than those of the previous day, however, after 2 hours of work, the previous indicators were again achieved and the catalyst again reached the stationary level.

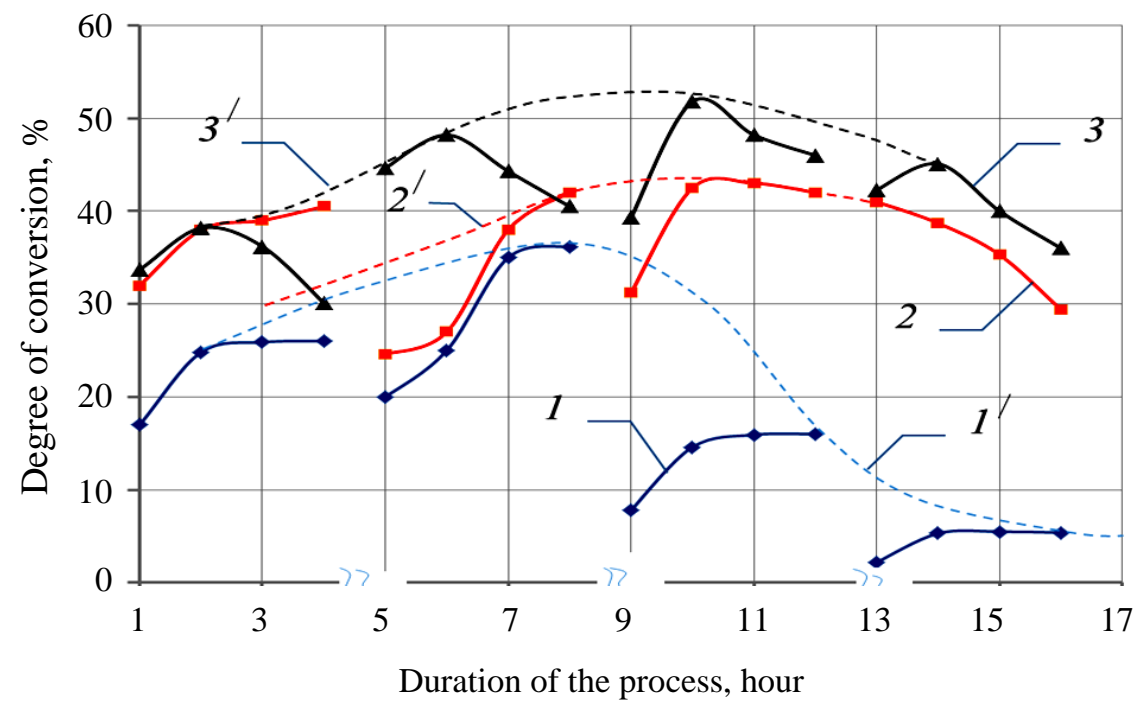

Fig.3. The influence of the duration of the process on the degree of conversion of isopropyl alcohol in the presence of $\eta-\mathrm{Al}_{2} \mathrm{O}_{3}$ at different temperatures: $1-150,2-200,3-250{ }^{\circ} \mathrm{C}$ (dashed lines refer to the corresponding trend lines at the temperatures, ${ }^{0} \mathrm{C}: 1-150,2-200,3-250$ ). 
It should be noted that the catalytic activity manifested by $\eta-\mathrm{Al}_{2} \mathrm{O}_{3}$ varied in different ways depending on the temperature of the process over a long period. So, at the temperature of $150^{\circ} \mathrm{C}$, the degree of conversion of alcohol dropped sharply after only 8 hours of work, while at higher temperatures the catalytic activity maintained for 14-15 hours.

In the presence of $\eta-\mathrm{Al}_{2} \mathrm{O}_{3}$, isopropyl alcohol is converted in two directions (figure 4): dehydration to propylene by the $E 1$ mechanism and to diisopropyl ether by $S_{N} 2 \beta$-elimination (the latter is characteristic of basic oxides, and their yield is associated with the prevalence of one or another direction of these two competing processes and, accordingly, the nature of acid sites on the catalyst surface, the highest yield of diisopropyl ether was observed at a temperature of $250^{\circ} \mathrm{C}$ during the period of work of $\eta-\mathrm{Al}_{2} \mathrm{O}_{3}$ catalyst from 3 to 9 hours.

Figure 5 presents the dependences of the influence duration of the process on the degree of conversion of isopropyl alcohol in the presence of modified $\mathrm{HPA} / \eta-\mathrm{Al}_{2} \mathrm{O}_{3}$ catalysts. The results indicate that the presence of HPA ambiguously affects the activity of the catalyst: a sample containing a small amount $(5 \%)$ of the HPA is characterized by a low degree of alcohol conversion, however, with an increase in the content of the HPA in the catalyst to $7-10 \%$, the picture changes sharply to the opposite. The maximum degree of conversion of the raw material was noted when participating in the process of a 10\% HPA-containing sample and was $56 \%$. A sharp decrease in the degree of conversion of alcohol in the presence of a 13\% HPAcontaining sample is probably due to its rapid deactivation.

Also noteworthy is the stability of the manifested catalytic properties during the process, although here a period of activation was observed as well, similar to that noted above for unmodified analogues. In addition, modified samples containing 5, 7, 10 and $13 \%$ of HPA showed high selectivity for oxygen-containing products (Table): the selectivity of the $7 \%$ HPA-containing sample is 3.5 times higher than that of the unmodified. A characteristic feature of the influence of HPA is also the presence of acetone in the reaction products (in the presence of the initial sample, acetone was not formed).

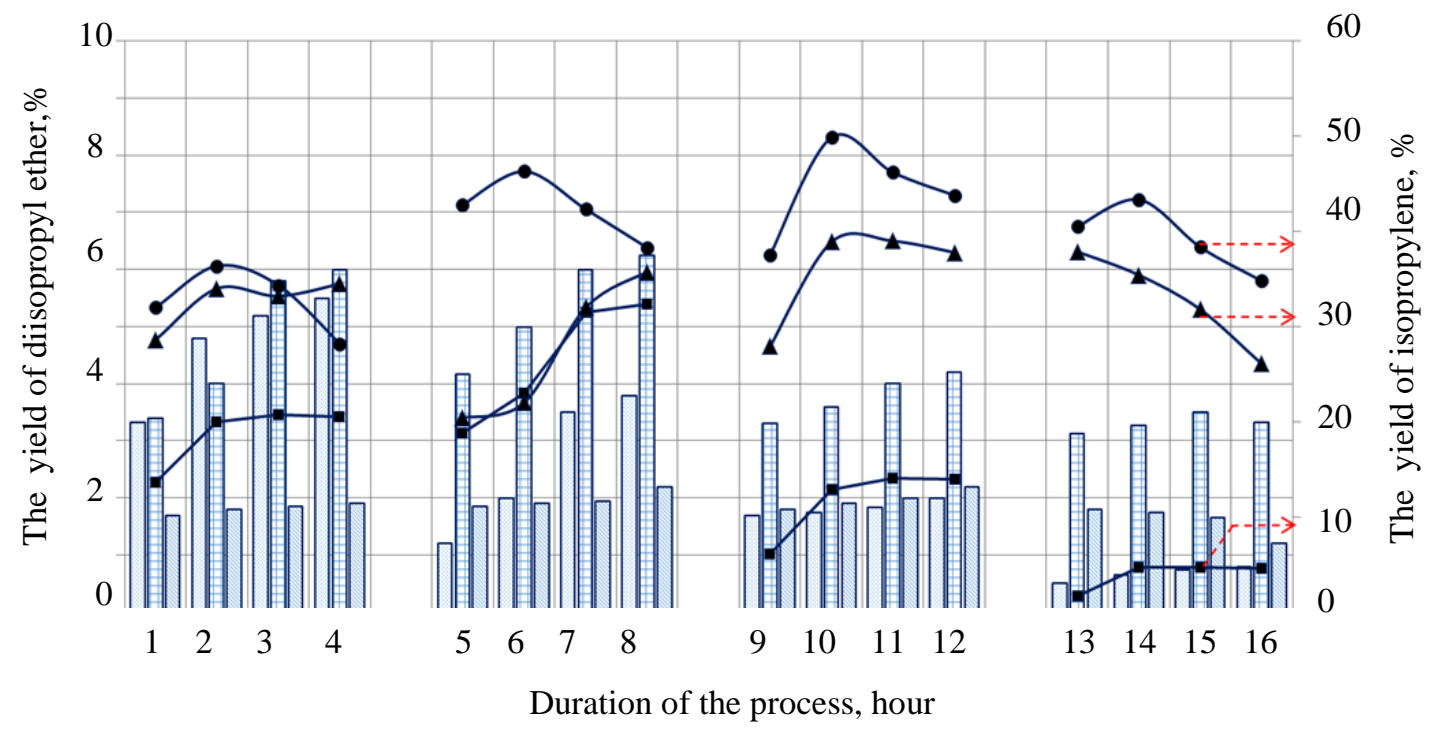

Fig. 4. Influence of duration of the process on the yield of diisopropyl alcohol (histograms) and propylene (solid lines) in accordance with $\eta-\mathrm{Al}_{2} \mathrm{O}_{3}$ at various temperatures, ${ }^{0} \mathrm{C}$ : $\mathrm{Q}-150$, $\square-200, \mathrm{Q}-250$. 


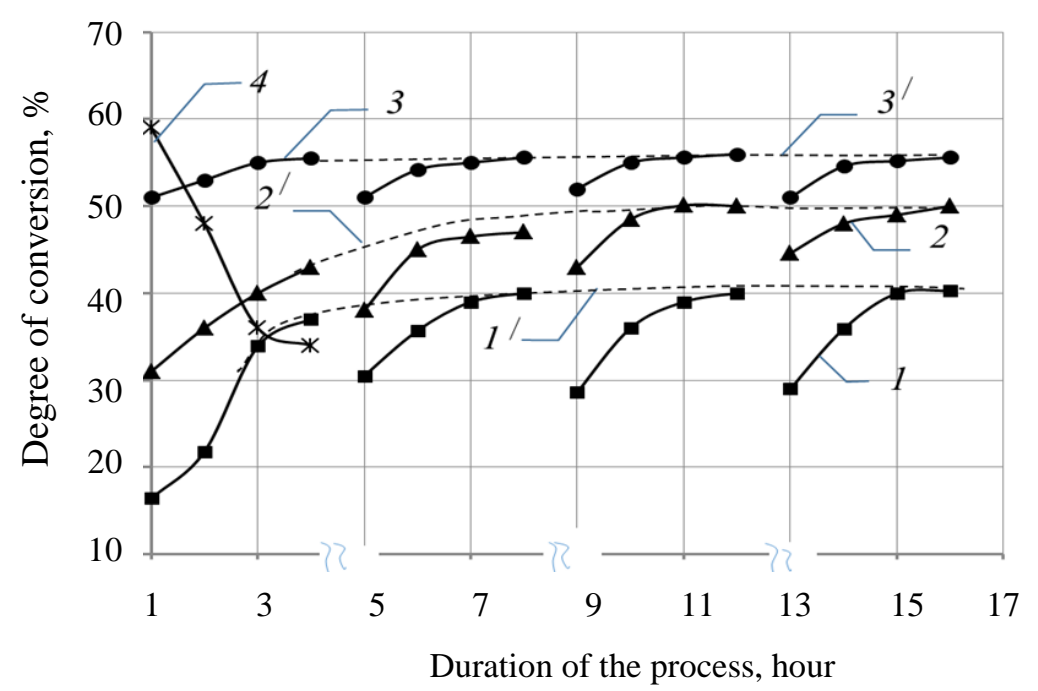

Fig.5. The effect of the duration of the process on the degree of conversion of isopropyl alcohol in the presence of $\mathrm{HPA} / \eta-\mathrm{Al}_{2} \mathrm{O}_{3}$ catalysts, in which the content of HPA, \%: $1-5$, $2-7,3-10,4-13$ (dashed lines refer to the corresponding trend lines with the contents of the HPA, \%: $\left.1^{\prime}-5,2^{\prime}-7,3^{\prime}-10 \% ; 4^{\prime}-13\right)$. Temperature of the process is $230^{\circ} \mathrm{C}$.

The relationship of the composition of the catalyst with a process indicator and the ratio of reaction products

\begin{tabular}{|c|c|c|c|c|c|c|c|}
\hline Catalyst & $K, \%$ & $\begin{array}{c}\text { Duration, } \\
\text { hour* }\end{array}$ & $\mathrm{S}, \%$ & $\begin{array}{c}\alpha_{\text {acetone, }} \\
\text { vol.\% }\end{array}$ & $\begin{array}{c}\alpha_{\text {ether }}, \\
\text { vol.\% }\end{array}$ & $\mathrm{C}_{3} \mathrm{H}_{6} / \mathrm{OCC}^{*}$ & $\mathrm{C}_{3} \mathrm{H}_{6} \mathrm{O} / \mathrm{C}_{6} \mathrm{H}_{14} \mathrm{O}$ \\
\hline $\begin{array}{c}\eta-\mathrm{Al}_{2} \mathrm{O}_{3} \\
\text { (without HPA) }\end{array}$ & 42 & 8 & 14.9 & - & 6.25 & 5.72 & - \\
\hline $\begin{array}{c}\eta-\mathrm{Al}_{2} \mathrm{O}_{3}+5 \% \\
\mathrm{HPA}\end{array}$ & 44.6 & 7 & 46.6 & 16.3 & 4.5 & 1.44 & 3.62 \\
\hline $\begin{array}{c}\eta-\mathrm{Al}_{2} \mathrm{O}_{3}+7 \% \\
\mathrm{HPA}\end{array}$ & 50.1 & 11 & 52.1 & 17.4 & 8.7 & 0.92 & 2.0 \\
\hline $\begin{array}{c}\eta-\mathrm{Al}_{2} \mathrm{O}_{3}+10 \% \\
\mathrm{HPA}\end{array}$ & 54.3 & 3 & 40.1 & 14.5 & 7.3 & 1.49 & 1.99 \\
\hline $\begin{array}{c}\eta-\mathrm{Al}_{2} \mathrm{O}_{3}+13 \% \\
\mathrm{HPA}\end{array}$ & 59.2 & 1 & 28.5 & 10.2 & 6.7 & 2.50 & 1.52 \\
\hline
\end{tabular}

* the indicated degree of alcohol conversion and the duration of the process correspond to the highest yield of oxygencontaining compounds for this sample; $T=200^{\circ} \mathrm{C}$.

The nature of the resulting products suggests that the active centers of unmodified aluminum oxide are exclusively Lewis centers strong acid Lewis centers and strong base Lewis centers, which are responsible for high propylene content ( $E 1$ mechanism; taking into account the low temperatures of the process, the contribution of propylene formation from ether can be neglected) and ether ( $S_{N} 2$ mechanism), respectively. Given the high ratio of propylene to the total yield of oxygen-containing, it can be supposed that on the $\eta-\mathrm{Al}_{2} \mathrm{O}_{3}$ surface, strong Lewis acid sites constitute the majority, what accords well with the literature data $[11,17,28]$.
For the convenience of consideration the contribution of Lewis acid centers and basic centers (both Lewis and Brensted), let's consider the ratio of the reaction products formed on them:<smiles>CCCCCC(C=CC(CCC)CCOC)CCC</smiles>

A comparative analysis of the reaction products formed in the presence of modified samples showed that the input of 5\% HPA leads to a sharp increase in the yield of acetone (the 
highest ratio of acetone/ether and one of the highest propylene/KCC), while the highest yield of KCC compounds the sample with $7 \%$ of HPA, by contrast, has the lowest ratio of propylene to KCC. Consequently, the active centers of the latter are represented mainly by bases, which, according to the ratio of acetone to ether, are the bases of Brensted. It should be noted that the prevalence of acetone over ether is characteristic of all modified samples and is fundamentally different from the unmodified one. An increase in the content of HPA to 10 and further to $13 \%$ is accompanied by the contribution of Lewis acid centers and decrease in the contribution of basic ones. Despite the seeming inconsistency, such results are possible if we assume that during sorption of the HPA on $\eta-\mathrm{Al}_{2} \mathrm{O}_{3}$ it loses its structure.

The totality of the considered data suggests the following mechanism for the evolution of the active centers of the system HPA/aluminum oxide.

I. Initially on the surface of the oxide there are present: LAC coordination unsaturated oxygen atoms (coordinately-unsaturated aluminum atoms $\mathrm{Al}^{3+}$ ) and LOC (coordinatelyunsaturated oxygen atoms $\mathrm{O}^{2-}$ ); not showing catalytic activity, however, marked by the results of IR studies (bridge and terminal hydroxide groups) indicate the presence of a certain amount of BAC, which according to currently the most complete and most appropriate level of modern knowledge about aluminum oxide [23, 29] Knoesinger-Ratnas model have the following structure:

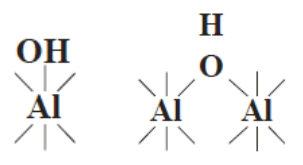

II. At the stage of HPA modification, interaction (possible multipoint dissociative adsorption of HPA) of its cation with a hydroxyl group dehydration) of $\mathrm{BAC}$ with the transition to the LAC (on the IR spectra of the modified samples, the bands of the bridge and terminal hydroxide groups disappear occurs.
III. LAC that are present on the surface interact with the HPAn (Heteropolyanion), forming a surface complex. Considering that the highest electron density in the HPAn is concentrated on the oxygen atoms in the $\mathrm{M}-\mathrm{O}-\mathrm{M}$ corner groups, it is through the oxygen of this group that the bond with the LAC is formed.

IV. Taking into account that $\eta-\mathrm{Al}_{2} \mathrm{O}_{3}$ is characterized mainly by weak LAC, the HPAn charge will be only partially compensated, then the surface complex will exhibit the properties of the BBC - a hydrogen acceptor, what was noted during catalytic studies.

Thus, taking into account the totality of the obtained data and the results of the catalytic activity of the $\mathrm{HPA} / \eta-\mathrm{Al}_{2} \mathrm{O}_{3}$ system during the process of conversion of isopropyl alcohol, it can be assumed that the interaction of the Keggin structure with the basic oxide leads to the destruction of its structure with the formation of a HPAn. The latter, possessing a negative charge, interacts with electron-acceptor centers - LAC - on the surface. In accordance with the authors' results[17, 20, 23,29], the concentration of weak LACs on the $\eta-\mathrm{Al}_{2} \mathrm{O}_{3}$ surface is several times higher than the content of medium and strong (there are practically no last), as a result of which the HPA interaction probably occurs, with weak acid centers that cannot fully compensate for the negative charge of HPA. As a result of this, a surface complex of the surfaceligand type, which has a negative charge, is formed, which then starts acting as a hydrogen acceptor-that probably appeared after the modification of catalytic properties of BBC.

\section{References}

1. Nikitina E.A. Geteropolisoedineniia. M.: Goshimizdat, 1962. $422 \mathrm{~s}$.

2. Pop M.S. Geteropoli- i izopolioksometallaty. Novosibirsk: Nauka. Sib. otd-nie, 1990. 232 s.

3. Maksimov G.M. Dostizheniia v oblasti sinteza polioksometallatov i izucheniia geteropolikislot. Uspehi himii. 1995. T. 64. № 5. S. 480-496.

4. Xavier López, Jorge J. Carbó, Carles Bo, Josep M. Poblet. Structure, properties and reactivity of polyoxometalates: a theoretical perspective. Chem. Soc. Rev. 2012. No 41. P. 7537-7571.

5. Tagiyev D., Munshieva M., Zulfugarova S. Silica supported heteropoly acids as selective catalysts 
for $\mathrm{C}_{6}-\mathrm{C}_{8}$-olefins dimerization. Azerb. Chem. Journ. № 2. 2011. P. 103-107.

6. Kozhevnikov I.V. Kataliz geteropolisoedineniiami. M.: Znanie. 1985. $32 \mathrm{~s}$.

7. Timofeeva M.N. Kislotnost i kataliticheskie svoistva gomogennykh i geterogennykh sistem na osnove GPS. avtoref. dis. ... dokt. him. nauk: 02.00.15. Timofeeva M. N. novosibirsk. RAN: 2010. $37 \mathrm{~s}$.

8. Timofeeva M. H., Hanhasaeva S. TC. Metody regulirovaniia fiziko-himicheskikh i kataliticheskikh svoi`stv sloisty`kh aliumosilikatov. Kinetika i kataliz. 2009. T. 50. № 1. S. 1-9.

9. Ivanova A.S. Oksid aliuminiia i sistemy` na ego osnove: svoistva, primenenie. Kinetika i kataliz. 2012. Т. 53. № 4. S. 446-460.

10. Ismagilov Z.R., Shkrabina R.A., Koriabkina N.A. Aliumooksidnye nositeli: proizvodstvo, svoistva i primenenie $\mathrm{v}$ kataliticheskikh protcessakh zashchity okruzhaiushchei sredy: Analit. obzor. SO RAN. GPNTB; In-t kataliza im. G.K. Boreskova. Novosibirsk. 1998. Ser. Ekologiia. Vyp. 50. 82 s.

11. Chukin G.D. Stroenie oksida aliuminiia i katalizatorov gidroobesserivaniia. Mehanizmy reaktcii. M.: Tipografiia Paladin, OOO "Printa", 2010. $288 \mathrm{~s}$.

12. Alberto M. Becerra María E Iriarte, Adolfo E. Castro Luna. Catalytic activity of a nickel on alumina catalyst in the $\mathrm{CO}_{2}$ reforming of methane. Reaction Kinetics and Catalysis Letters. 2003. V. 79. I. 1. P. 119-125.

13. Kim P.J., Joo B.H., Kim W., KimY., KimI.K., Song J.Yi. Preparation of Mesoporous Nialumina Catalyst by One-step Sol-gel Method: Control of Textural Properties and Catalytic Application to the Hydrodechlorination of $O$ dichlorobenzene. Catalysis Letters. 2005. V. 104. I. 3-4. P. 181-189.

14. Lanin S.N., Bannykh A.A., Vinogradov A.E., Kovaleva N.V., Lanina K.S., Nicolaev S.A. Adsorbtcionnye svoistva oksida aliuminiia, modifitcirovannogo nanochastitcami palladiia, zolota i oksida tcerii. Zhurn. Fiz. Himii. 2016. T. 90. № 7. S. 1047-1053.

15. Chumachenko V.A., Ovchinnikova E.V. Aktivnost promyshlennykh katalizatorov na osnove oksida aliuminiia $\mathrm{v}$ degidratatcii etanola $\mathrm{v}$ etilen. Kataliz v promyshlennosti. 2015. T. 15. № 6. S. 31-35.

16. Lavrenov A.V., Dupliakin V.K. Oligomerizatciia butenov na boratsoderzhashchem okside aliuminiia. Kinetika i kataliz. 2009. T. 50. № 2. S. 249-255.

17. Kotlovanova N.E., Matveeva A.N., Omarov Sh.O., Sokolov V.V., Akbaeva D.N., Popkov V.I. Formirovanie i kislotnye svoistva poverkhnosti vysokodispersnykh nanoporoshkov $\eta-\mathrm{Al}_{2} \mathrm{O}_{3}$.
Neorgan. Mater. 2018. T. 54. № 4. S. 410418.

18. Sung D.M., Kim Y.H., Par E.D., Yie J.E. Correlation between acidity and catalytic activity for the methanol dehydration over various aluminum oxides. Research on Chemical Intermediates. 2010. V. 36. P. 653-660.

19. IK-spektry i spektry KR neorganicheskikh i koordinatcionny`kh soedinenii`. Per s angl. M.: Mir. 1991. $536 \mathrm{~s}$.

20. Ivanova A.S. Leetvak G.S., Kriukova G.N., TCybulia S.V., Paukshtis E.A. Realnaia struktura metastabilnykh form oksida aliuminiia. Kinetika i kataliz. 2000. T. 41. № 1. S. 137-141.

21. Paukshtis E.A. IK-spektroskopiia v geterogennom kislotno-osnovnom katalize. Novo-sibirsk: Nauka, 1992. $256 \mathrm{~s}$.

22. Chukin G.D., Sergienko S.A., Seleznev Iu.L., Malevich V.I., Radchenko E.D. Infrakrasnye spektry oksida aliuminiia, modifitcirovannogo molibdenom. Zhurn. pricl. spektroskopii. 1987. T. 47. № 3. S. 427-432.

23. Romanova R.G., Petrova E.V. Kislotno-osnovnye svoistva poverkhnostnykh binarnykh sistem na osnove oksidov aliuminiia i tcirkoniia. Kinetika i kataliz. 2006. T. 47. № 1. S. 141-150.

24. Tveritinova E.A., Zhitnev Iu.N., Cherniak S.A., Arhipova E.A., Savilov S.V., Lunin V.V. Kataliticheskaia konversiia alifaticheskikh spirtov na uglerodnykh nanomaterialakh. rol struktury i funktcionalnykh poverkhnostnykh grupp. Zhurn. fiz. himii. 2017. T. 91. № 3. S. 429-435.

25. Aliyev A.M., Mejidova. S.M., Ali-zade G.A., Agayeva R.Yu. Oxidative conversion of methanol over the modified zeolites. Azerb. Chem. Journ. № 1. 2013. P. 9-18.

26. Guseinova E A., Zeinalov E.T., Adzhamov K.Yu. Commercial Nickel-Kieselguhr Isopropanol Dehydrogenation Catalysts: Morphology and Catalytic and Electronic Properties. Catalysis in Industry. 2015. V. 7. Issue 3. P. 227-233.

27. Serp P., Corrias M., Kalck P. Carbon nanotubes and nanofibers in catalysis. Applied Catalysis A: General. 2003. V. 253. P. 337-358.

28. Lundie D.T., McInroy A.R., Marshall R., Winfield J.M., Jones P., Dudman C.C., Parker S.F., Mitchell C., Lennon D. Improved description of the surface acidity of $\eta$-alumina. J. of Phys. Chem. B. 2005. V. 109. P. 11592-11601.

29. Lamberov A.A., Romanova R.G., Shmelev I.G., Sopin V.F. Vliianie kislotnogo modifitcirovaniia na strukturu i kataliticheskuiu aktivnost' oksida aliuminiia Zhurn. pricl. himii. 2002. T. 45. Vyp. 3. S. 407-412. 


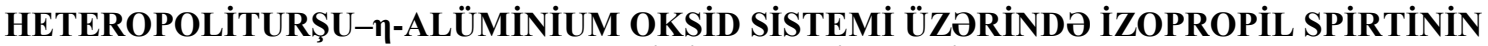 KATALITIK ÇEVRILLMOSI}

\section{E.Ә.Hüseynova, S.E.Yusubova, K.Y.Әcəmov}

Heteropoliturşu- $\eta$-alüminium oksid sistemi üzərində izopropil spirtinin katalitik çevrilməsinin nəticələri müzakirə edilmişdir. Reaksiya məhsullarının müqayisəli analizi əsasında müəyyən edilmişdir ki, modifikasiya edilməmiş $\eta$ alüminium oksidin aktiv mərkəzləri əsasən Lyuis mərkəzləri - güclü Lyuis turşu mərkəzləri və güclü Lyuis əsasi mərkəzlərindən ibarətdir, halbuki heteropoliturşularla modifikasiyadan sonra onlar əsasən əsasi mərkəzlər - Brensted əsaslarından ibarət olmuşdur. alınmış sistemlər rentgenfaza analizi, skanlayıcı elektron mikroskop, element analizi, İQspektroskopiya üsulları ilə xarakterizə edilmişdir. Alınmış nəticələrin cəmi müəyyən etməyə imkan verir ki, Keqqin strukturunun əsas oksid ilə qarşılıqlı təsiri zamanı onun dağılması və heteropolianionun əmələ gəlməsi baş verir ki, bu da mənfi yükə malik olaraq, səthdə mövcud olan elektron-akseptor Lyuis turşu mərkəzləri ilə qarşılıqlı təsirdə olaraq səth - liqand tipli səth kompleksi əmələ gətirir, bu da kompensasiya olunmamış mənfi yükə malik olaraq sonradan yeni Brensted əsası rolunu oynamağa başlayır.

Açar sözlor: izopropil spirti, $\eta$-alüminium oksid, heteropoliturşu, kataliz.

\section{КАТАЛИТИЧЕСКИЕ ПРЕВРАЩЕНИЯ ИЗОПРОПИЛОВОГО СПИРТА НА П-ОКСИДЕ АЛЮМИНИЯ, МОДИФИЦИРОВАННОМ ГЕТЕРОПОЛИКИСЛОТОЙ}

\section{Э.А.Гусейнова, С.Э.Юсубова, К.Ю.Аджамов}

Изучены каталитические свойства ๆ-оксида алюминия, модифицированного фосформолибденовой гетерополикислотой, в процессе превращения изопропилового спирта. Установлено, что модифицирование приводит к увеличению его активности и селективности по кислородсодержащим продуктам. С применением сканирующей электронной микроскопии, элементного анализа и ИК-спектроскопии выявлены текстурные и спектроскопические особенности модифицированного ๆ-оксида алюминия и высказаны предположения о механизме их влияния на каталитическую активность в процессе превращения изопропилового спирта.

Ключевые слова: изопропиловый спирт, п-оксид алюминия, фосформолибденовая гетерополикислота, каталитические свойства. 